OPEN ACCESS

Edited by:

Alberto Basset,

University of Salento, Italy

Reviewed by:

Dirk de Beer,

Max Planck Society, Germany

*Correspondence:

Kasper Elgetti Brodersen kasper.elgetti.brodersen@bio.ku.dk

Specialty section: This article was submitted to Marine Ecosystem Ecology, a section of the journal Frontiers in Marine Science

Received: 24 November 2021

Accepted: 31 January 2022

Published: 21 February 2022

Citation:

Brodersen KE and Kühl M (2022) Effects of Epiphytes on the Seagrass

Phyllosphere.

Front. Mar. Sci. 9:821614. doi: 10.3389/fmars.2022.821614

\section{Effects of Epiphytes on the Seagrass Phyllosphere}

\author{
Kasper Elgetti Brodersen* and Michael Kühl \\ Marine Biological Section, Department of Biology, University of Copenhagen, Helsingør, Denmark
}

The seagrass phyllosphere consists of a dynamic mosaic of physico-chemical microgradients that modulate light harvesting, gas and nutrient exchange between the photosynthetic leaves and the surrounding water-column. The phyllosphere is thus of vital importance for seagrass growth and fitness. However, unfavorable environmental conditions such as water-column hypoxia, increasing temperature and high nutrient inputs that are predicted to increase in frequency and severity in the Anthropocene, can render the leaf microenvironment into a hostile microhabitat that is challenging or even harmful for the plants-especially if leaves are covered by epiphytic biofilms. Here we summarize effects of epiphytic biofilms on seagrass leaves and discuss how they change and affect the biogeochemical processes and chemical conditions in the seagrass phyllosphere. During night-time, water-column hypoxia can lead to anoxic conditions at the leaf/epiphyte interface, reducing diffusive $\mathrm{O}_{2}$ supply and thus $\mathrm{O}_{2}$ availability for plant respiration and transport to below-ground tissues. Furthermore, anoxia in epiphytic biofilms can also enable anaerobic microbial processes that can lead to harmful nitric oxide production via denitrification. Such microenvironmental stress conditions at night-time are exacerbated by increasing temperatures. In the light, the leaf epiphytic biofilm community often results in lower leaf photosynthetic activity and efficiency due to epiphyte-induced shading and a combination of $\mathrm{O}_{2}$ build-up and $\mathrm{CO}_{2}$ reduction in the phyllosphere owing to thicker total diffusional pathways, phyllosphere basification and epiphytic carbon fixation. Furthermore, absorbed light energy in the epiphytic biofilm can also drive an increase in the leaf surface temperature relative to the surrounding seawater potentially aggravating heating events in the surrounding seawater. In combination, all these above-mentioned diurnal effects of epiphytes result in higher compensation photon irradiance of epiphyte-covered leaves and thus higher light requirements of seagrasses.

Keywords: Anthropocene, light, microenvironment, oxygen, $\mathrm{pH}$, photosynthesis, temperature, toxins

\section{INTRODUCTION}

Seagrasses are marine angiosperms that have adapted to a life in an aqueous environment rooted in reduced, anoxic sediments by evolving internal gas channels (aerenchyma) enabling low-resistance, intra-plant gas transport to below-ground tissues (Armstrong, 1979; Colmer, 2003), and leaves with primary photosynthetic tissue in the epidermis that lack stomata and bares a thin cuticle 
(Larkum et al., 2006). Seagrasses are highly productive marine plants that form densely populated meadows, which provide important ecosystem services, such as: (i) increasing the $\mathrm{pH}$ and $\mathrm{O}_{2}$ level in the surrounding water-column during daytime with positive effects on calcifying organisms like corals (Greve et al., 2003; Ricart et al., 2021); (ii) providing coastal protection against erosion owing to leaf-induced wave attenuation (Ward et al., 1984; Fonseca and Cahalan, 1992); (iii) offering versatile feeding and nursery grounds especially for juvenile fish (Bertelli and Unsworth, 2014); (iv) absorbing nutrients such as $\mathrm{N}$ and $\mathrm{P}$ leading to improved water quality (McRoy and Barsdate, 1970; Pernice et al., 2016); (v) efficient sequestration of fixed carbon into the sediment and thus mitigating climate change (Duarte et al., 2005; Fourqurean et al., 2012). Healthy and productive seagrass leaf canopies are thus important for ensuring a good environmental state of marine waters, especially in coastal regions. However, seagrasses are challenged by global climate change and regional anthropogenic stressors encompassing rising seawater temperatures, ocean deoxygenation, and coastal eutrophication that have detrimental effects on plant performance and health (Waycott et al., 2009; Raun and Borum, 2013; Brodersen et al., 2015a,b, 2020a,b; Pedersen et al., 2016; Noisette et al., 2020; Rasmusson et al., 2020; Nguyen et al., 2021).

Increasing temperature can e.g., lead to a negative $\mathrm{O}_{2}$ balance in the seagrass plant, owing to a decreasing net photosynthesis above the plant's temperature optimum (about $24^{\circ} \mathrm{C}$ in temperate seagrasses and $>30^{\circ} \mathrm{C}$ in tropical species). This is due to enzyme capacity limitations and denaturation of proteins involved in photosynthesis, whereas the plant respiration rate continues to increase strongly with increasing temperature (Staehr and Borum, 2011; Pedersen et al., 2016). Ocean deoxygenation can also result in inadequate plant aeration via limited $\mathrm{O}_{2}$ diffusion into the seagrass leaves, which especially affects the below-ground tissue at night-time and can lead to increased mortality owing to sulfide intrusion (Holmer and Bondgaard, 2001; Pedersen et al., 2004; Borum et al., 2005). Coastal eutrophication, leads to algal blooms in the water-column and enhanced epiphyte growth on seagrass leaves (Borum et al., 1984; Borum, 1985; Frankovich and Fourqurean, 1997; Burkholder et al., 2007; Ralph et al., 2007), which shade the leaves during daytime (Brush and Nixon, 2002; Brodersen et al., 2015a). This leads to reduced leaf photosynthesis (Sand-Jensen, 1977; Brodersen et al., 2015a) and increases the water-column and leaf biofilm $\mathrm{O}_{2}$ demand during night-time (Diaz and Rosenberg, 2008; Brodersen et al., 2015a). All of the above-mentioned environmental challenges often act in synergy and thus deteriorate seagrass health. Leaf epiphytic biofilm communities also challenge their seagrass host by generating an extreme leaf microenvironment, especially in the epiphyte micro-understory, leading to carbon limitation and enhanced photorespiration during daytime, and low $\mathrm{O}_{2}$ availability and potentially phytotoxic nitric oxide (NO) production in the leaf microenvironment at night-time (Brodersen et al., 2020a,b; Noisette et al., 2020). Furthermore, leaf infection with the pathogenic marine slime mold-like protist Labyrinthula, also known as wasting disease, have previously shown to cause large scale die-off events of seagrass meadows (Sullivan et al., 2013; Trevathan-Tackett et al., 2018); a disease that is predicted to worsen with global warming and increased precipitation (Sullivan et al., 2018). Seagrasses can alleviate epiphyte colonization via production of zosteric acid (ZA) an effective antifoulant (Newby et al., 2006) that has been shown to reduce bacterial and fungal attachment and formation on surfaces (Villa et al., 2010; Jendresen and Nielsen, 2019). However, although the production of ZA can reduce the initial colonization of leaves with epiphytes, such defense mechanism appears insufficient to avoid overgrowth under coastal eutrophication events. Epifauna can also mitigate the epiphyte pressure on seagrass leaves as they function as grazers in seagrass meadows (Orth and Van Montfrans, 1984; Orth et al., 1984), where this reduction in leaf epiphyte biomass likely positively effects nutrient cycling in the ecosystems via epifaunal nutrient excretion. Last not least, leaf epiphytes have also been shown to be beneficial for seagrasses by enhancing the bioavailable amount of inorganic nitrogen via mineralization of dissolved organic nitrogen accommodated by microorganisms on the leaf surface; thus, enhancing the productivity and growth rate of the hosting seagrass meadows (Tarquinio et al., 2018).

In this mini-review, we focus on the seagrass leaf phyllosphere and how its microenvironment is affected by environmental change in the Anthropocene, especially eutrophication-induced epiphyte overgrowth of leaves that can have strong detrimental impact on seagrasses in future oceans (e.g., York et al., 2016).

\section{THE PHYSICAL MICROENVIRONMENT OF THE SEAGRASS LEAF PHYLLOSPHERE}

\section{Impedance of Mass Transfer in the Phyllosphere}

Epiphytic biofilms strongly affect the light microclimate as well as the mass and heat transfer across the leaf tissue surface (Figure 1; Brodersen et al., 2015a; Noisette et al., 2020). Seagrass leaves (and most other flow exposed aquatic surfaces) are surrounded by a diffusive boundary layer (DBL) that is generated by impeded water movement toward the leaf surface, leading to unstirred water conditions close to the leaf surface where mass transfer is predominated by diffusion (Jørgensen and Revsbech, 1985; Koch, 1994; Hurd, 2000). The average transport time for a molecule via molecular diffusion scales with the square of the distance, and mass transfer impedance imposed by the DBL thus depends strongly on its thickness. The DBL thickness is affected by factors like the flow velocity and the leaf surface topography, where low flow conditions and more rough leaf surfaces increase the DBL thickness (Jørgensen and Des Marais, 1990; Lichtenberg et al., 2017). Epiphytic biofilms can strongly accentuate such mass transfer impedance by increasing the total diffusional distance (TDD, i.e., the combined thickness of the biofilm and the overlying DBL thickness) between the seagrass leaf and the surrounding water, in combination with active removal of e.g., $\mathrm{O}_{2}$ in the epiphytic biofilm in darkness imposing strong $\mathrm{O}_{2}$ limitation (Brodersen et al., 2015a, 2020a,b). 


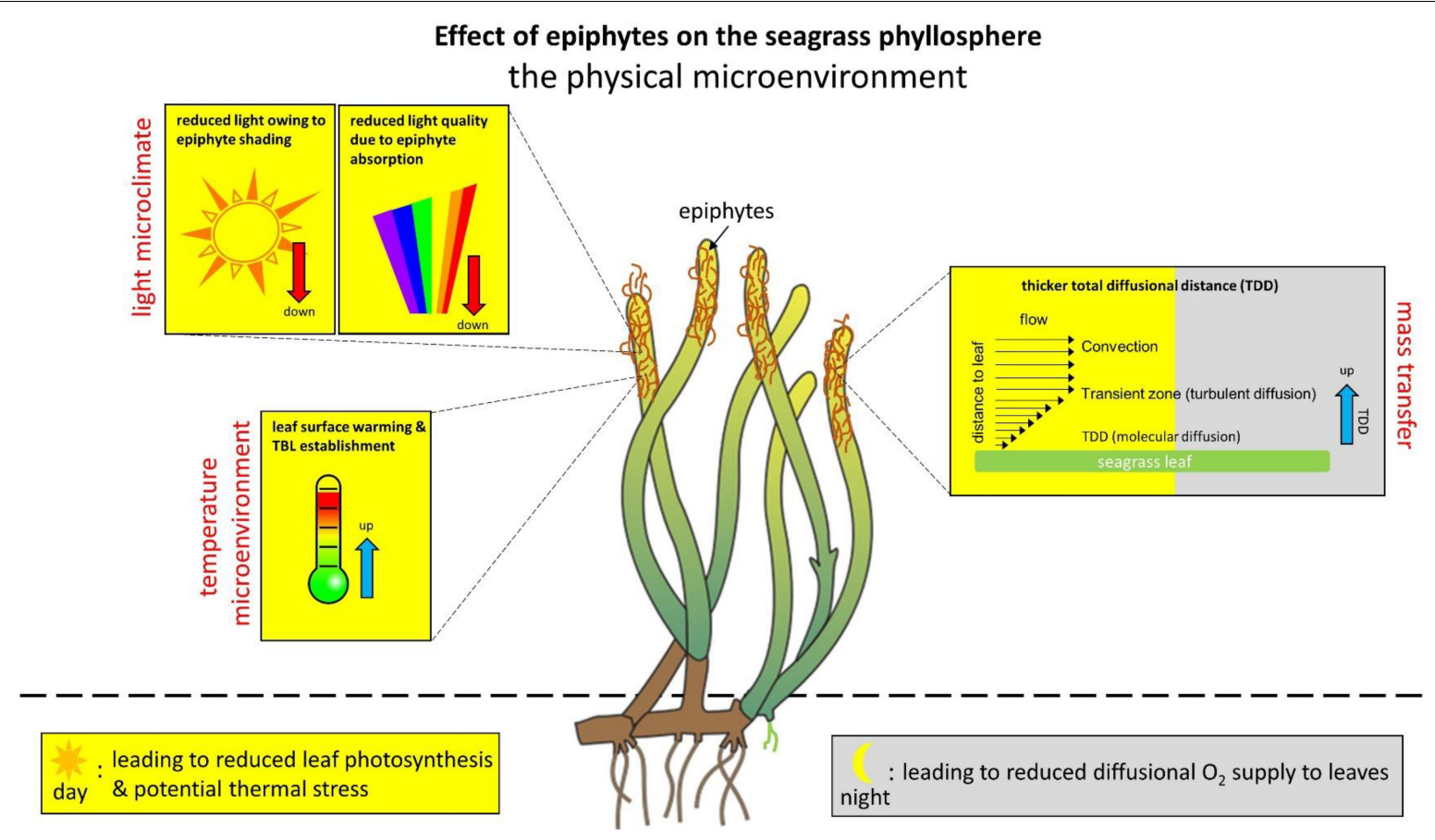

FIGURE 1 | Effect of epiphytes on the physical microenvironment in the seagrass phyllosphere. The changes in the phyllosphere physical microenvironment are shown as an effect on seagrass leaves with epiphytic biofilms as compared with bare leaves and/or bare leaf parts. The seagrass phyllopshere dynamics are shown over diel cycles, where the yellow marked areas represent alterations during daytime and gray marked areas represent changes during night-time. Blue arrows indicate an increase. Red arrows indicate a decrease.

\section{Light-Driven Heating of the Phyllosphere}

Absorbed solar radiation in densely pigmented epiphytic biofilms and tissues can lead to local heating, which is dissipated toward the overlying water via a leaf thermal boundary layer (TBL; Jimenez et al., 2008; Noisette et al., 2020). The TBL acts as an insulating barrier and therefore impedes heat dissipation (i.e., the rate of convective dissipation of heat) from the tissue surface (Jimenez et al., 2008, 2011; Brodersen et al., 2014). High irradiance can increase the leaf surface temperature up to $\sim 0.8^{\circ} \mathrm{C}$ relative to the ambient seawater (Noisette et al., 2020) and such leaf surface warming correlates linearly with the incident irradiance (under similar flow conditions) and is further enhanced by epiphytic overgrowth. The TBL thickness increases with decreasing flow velocity, increasing leaf surface topography and epiphytic overgrowth (Noisette et al., 2020), and is often much thicker than the TDD ( $\sim 4$ times wider) under slow to moderate flow velocities. Such seagrass leaf surface warming can potentially aggravate negative responses to extreme heat events and ongoing global warming, especially in regions where seagrasses live close to their thermal stress tolerance, but the role of the phyllosphere temperature microenvironment remains largely unexplored.

\section{Changes in the Light Microclimate of the Phyllosphere}

The presence of epiphytes reduces both light quality and quantity reaching the seagrass leaf surface (Drake et al., 2003;
Brodersen et al., 2015a; Noisette et al., 2020). The presence of epiphytes has been shown to reduce the photon scalar irradiance of photosynthetically active radiation (PAR; 400$700 \mathrm{~nm}$ ) at the seagrass leaf surface by about 50\%, depending on epiphyte thickness, composition and density (Brodersen et al., 2015a; Noisette et al., 2020); however, reductions of $>90 \%$ as compared to bare leaves have been recorded (Brodersen et al., 2015a). Depending on the structure of the epiphytic biofilms, compaction of the epiphytic biofilm under high flow conditions can further decrease the light intensity reaching the leaf surface (Noisette et al., 2020).

In the upper more loose epiphyte canopy, this decrease in scalar irradiance is mainly uniform across wavelengths within the PAR region, whereas blue and red light are strongly absorbed by algae in the understory of epiphytic biofilms (spanning the innermost $<1 \mathrm{~mm}$ above the leaf tissue surface) (Brodersen et al., 2015a). Such dramatic reduction in the blue and red wavelengths reaching the seagrass leaf surface below the epiphyte canopy leads to an unfavorable light microenvironment predominated by green light that is not effectively absorbed by the seagrass leaf chlorophylls ( $a$ and $b$ ). Consequently, epiphyte-covered leaves typically have an increased compensation photon irradiance, i.e., the photon irradiance required for producing enough $\mathrm{O}_{2}$ through photosynthesis to meet the plants own respiratory needs (Brodersen et al., 2015a). Furthermore, sediment resuspension and sedimentation of fine particles on seagrass leaves, which likely is promoted by epiphyte cover due to exopolymer excretion, also negatively affect light transmission through 
the water-column and the seagrass leaf microenvironment (Erftemeijer and Lewis, 2006; York et al., 2015; Brodersen et al., 2017a).

On top of declining light availability in turbid waters affected e.g., by eutrophication or dredging, epiphyte-induced reduced light quality at the seagrass leaf surface can thus further deprive the light microclimate to near or below minimal photon requirements for a positive net $\mathrm{O}_{2}$ balance (Brodersen et al., 2015a). This can lead to high seagrass mortality rates in heavily exposed areas, due to the relatively high light requirements of seagrass (approx. 10-20\% of the sea surface irradiance depending on seagrass species); with $Z$. marina placed in the high-end of the light requirement scale at $\sim 20 \%$ of the sea surface irradiance (Duarte, 1991; Dennison et al., 1993; Ballesteros et al., 2007; Larkum et al., 2018).

Microscale light measurements have mainly been performed on temperate Zostera sp. with epiphytes largely consisting of bacteria and microalgae dominated by green, brown and red algae; where the dominating algae group determines the color morph of the epiphytic community (i.e., typically green during spring and red in the autumn; Borum et al., 1984). However, calcifying epiphytes often appear white in color (often seen in the Mediterranean and the tropics) and therefore likely rather reflect light than absorb it; as e.g., observed with the skeleton in corals (Enriquez et al., 2005; Wangpraseurt et al., 2012; Brodersen et al., 2014). But such effects of epiphyte community compositions needs to be verified experimentally and thus deserves further attention in future studies.

\section{THE CHEMICAL MICROENVIRONMENT OF THE SEAGRASS LEAF PHYLLOSPHERE}

Leaf epiphytes also strongly affect the chemical microenvironment of the seagrass phyllosphere over diel cycles, generating extreme microenvironmental conditions for the seagrass leaf exposed to the epiphyte micro-understory, as compared with bare leaves (Figure 2). In the light, photosynthesis (both in the seagrass leaf and epiphytic biofilm) leads to a strong increase in $\mathrm{O}_{2}$ concentration in the seagrass phyllosphere of epiphyte-covered leaves due to restricted mass transfer over the TDD (Brodersen et al., 2015a, 2020a,b; Noisette et al., 2020). This results in markedly reduced efficiency of seagrass leaf photosynthesis due to enhanced photorespiration, as the high $\mathrm{O}_{2}$ to $\mathrm{CO}_{2}$ ratio favors the oxygenase function of $\mathrm{RuBisCO}$, which leads to reduced carbon fixation via leaf photosynthesis (Buapet and Björk, 2016; Larkum et al., 2018; Brodersen et al., 2020a; Rasmusson et al., 2020). Actually, in seagrass leaves covered by thick and dense epiphytic biofilms, the vast majority of the $\mathrm{O}_{2}$ production in the seagrass phyllosphere is produced by the epiphytes (i.e., photosynthesis by the epiphyte community can account for up to $\sim 70 \%$ of the total $\mathrm{O}_{2}$ production in the seagrass phyllosphere in light [Mazzella and Alberte, 1986; Noisette et al., 2020; Zhang et al., 2022]), and leaf epiphytes have also been shown to cause oxidative stress in seagrass (Costa et al., 2015).
During night-time, seagrasses are completely dependent on passive diffusion of $\mathrm{O}_{2}$ from the surrounding water-column into the leaves (Greve et al., 2003; Pedersen et al., 2004; Borum et al., 2005, 2006). Epiphytic biofilms intervene with such diffusive $\mathrm{O}_{2}$ supply via epiphyte respiration and an increased TDD leading to reduced plant respiration rates and hypoxic phyllosphere conditions, as well as establishment of anoxic microzones in the epiphyte micro-understory (Brodersen et al., 2020a,b; Noisette et al., 2020). In such epiphyte-driven anoxic microhabitats anaerobic microbial processes can produce phytotoxins such as nitric oxide (NO) via denitrification (Noisette et al., 2020), which can potentially be very harmful to the plant (Beligni and Lamattina, 2001; Arasimowicz and Floryszak-Wieczorek, 2007; Kumar et al., 2015). Anoxia in the seagrass phyllosphere can thus lead to multiple detrimental effects on the intra-plant conditions, however, leaf-associated microorganisms may also be beneficial to the seagrass plant. Epiphytic microbiota have thus been shown to increase the nitrogen availability for seagrasses by mineralizing amino acids via heterotrophic metabolism (Tarquinio et al., 2018), which may be further supplemented by diazotrophic cyanobacteria (Hamisi et al., 2013). Biogeochemical processes in the epiphytic biofilms may thus increase the nitrogen uptake of seagrass leaves and enable enhanced plant productivity and growth in nitrogen-limited waters. The nitrogen cycle and dynamics in the seagrass phyllosphere is, however, not well described and deserves further attention in future studies.

The leaf photosynthetic activity is likewise negatively affected by epiphytes as compared with bare leaves (Sand-Jensen, 1977; Drake et al., 2003), largely due to epiphyte-induced shading (Brodersen et al., 2015b; Larkum et al., 2018). Reduced photosynthesis leads to decreased carbohydrate synthesis and thus increases the risk of plant starvation (Falkowski and Raven, 2013), as well as less efficient $\mathrm{O}_{2}$ transport to distal roots and parts of the rhizome via the aerenchyma. The latter can lead to anaerobic metabolism in below-ground tissues and intrusion of phytotoxins like hydrogen sulfide into the seagrass plant from the surrounding sediment (Borum et al., 2006; Brodersen, 2016; Brodersen et al., 2018a).

In epiphyte-covered seagrass leaves, especially thick and dense microalgal biofilm communities, leaf photosynthesis drives a pronounced phyllosphere basification up to a $\mathrm{pH}$ of about 10. This leads to marked shifts in the phyllosphere carbon speciation from $\mathrm{CO}_{2}$ toward bicarbonate $\left(\mathrm{HCO}_{3}{ }^{-}\right)$and even further to carbonate ions $\left(\mathrm{CO}_{3}{ }^{2-}\right)$, resulting in a $\mathrm{CO}_{2}$ and $\mathrm{HCO}_{3}{ }^{-}$availability below the plants $\mathrm{CO}_{2}$ compensation point of about $0.6 \mu \mathrm{M} \mathrm{CO}_{2}$ for active leaf photosynthesis (Brodersen et al., 2020a). The phyllosphere basification, and thus strong reduction in $\mathrm{CO}_{2}$ and $\mathrm{HCO}_{3}{ }^{-}$availability, correlates with increasing irradiance and TDD (Brodersen et al., 2020a). In regions where the epiphytic community is dominated by calcifying epiphytes, such epiphyte-induced carbon limitation challenge in the light may be alleviated, as calcification generates $\mathrm{CO}_{2}$ owing to its effect on the carbonate system equilibria and thereby likely supplies inorganic carbon for RuBisCO (McConnaughey, 1991; Riebesell et al., 2000; Van Dam et al., 2021). Furthermore, aerobic respiration by grazing leaf epifauna (e.g., Orth and Van Montfrans, 1984) may also decrease the $\mathrm{O}_{2} / \mathrm{CO}_{2}$ ratio in the 


\section{Effect of epiphytes on the seagrass phyllosphere the chemical microenvironment}

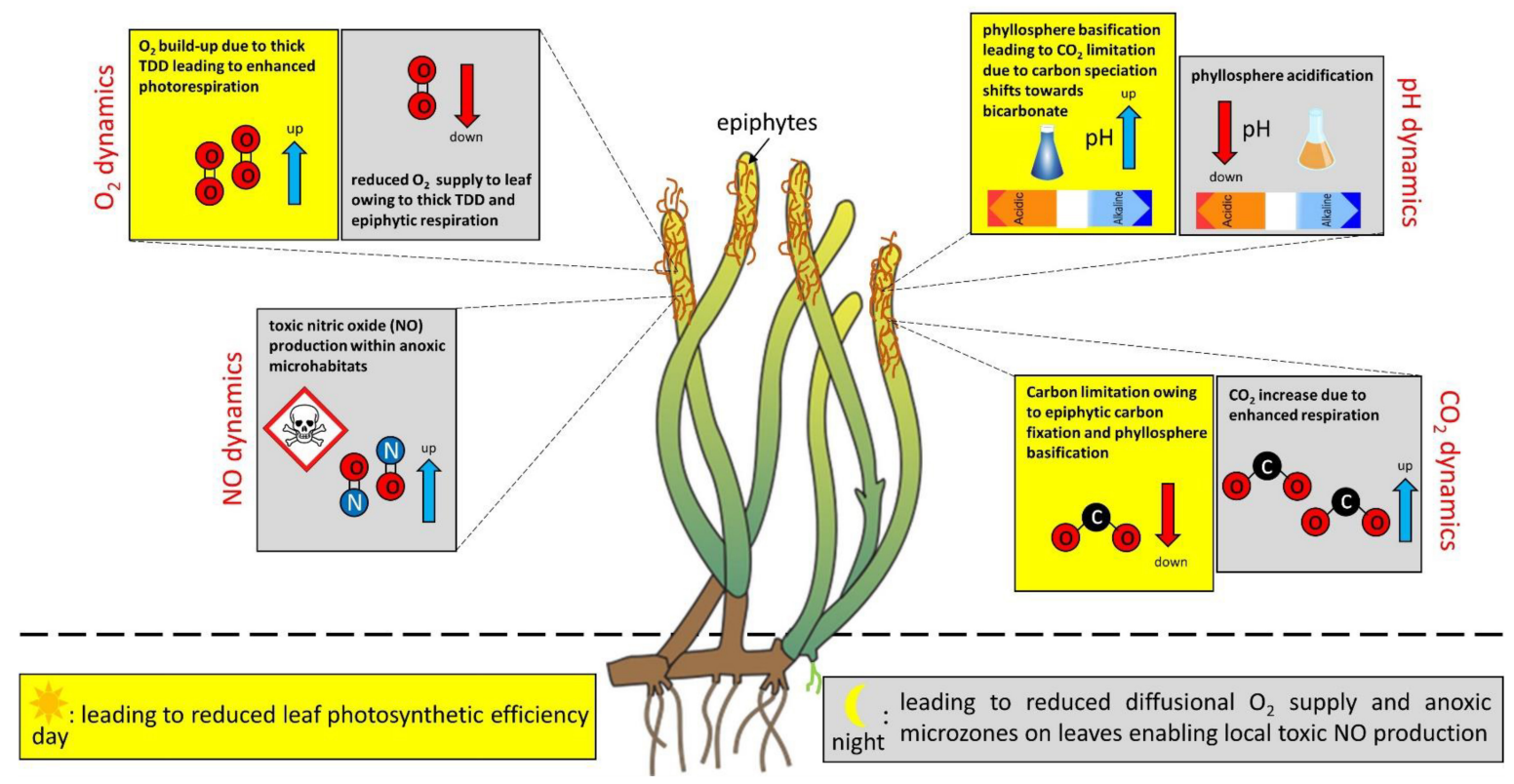

FIGURE 2 | Effect of epiphytes on the chemical microenvironment in the seagrass phyllosphere. The changes in the phyllosphere chemical microenvironment are shown as an effect on seagrass leaves with epiphytic biofilms as compared with bare leaves and/or bare leaf parts. The seagrass phyllopshere dynamics are shown over diel cycles, where the yellow marked areas represent alterations during daytime and gray marked areas represent changes during night-time. Blue arrows indicate an increase. Red arrows indicate a decrease.

seagrass phyllosphere. However, these speculations need to be verified experimentally and therefore deserve further attention in future studies. In darkness, on the other hand, the leaf surface $\mathrm{pH}$ of epiphyte-covered leaves reaches $\mathrm{pH} 7$, as compared to a more or less constant value of $\mathrm{pH} 8$ on the leaf surface of bare seagrass leaves, which is similar to the bulk water-column, in both light and darkness (Brodersen et al., 2020a).

Phyllosphere basification in combination with epiphytic carbon fixation can thus induce inorganic carbon limitation in seagrasses, where densely epiphyte-covered seagrass leaves have a strong dependence on $\mathrm{HCO}_{3}{ }^{-}$utilization for maintaining efficient photosynthesis-driven carbon fixation (Brodersen et al., 2020a). Seagrasses possess several $\mathrm{CO}_{2}$ concentration mechanisms (Beer et al., 1980, 2002; Beer and Rehnberg, 1997; Larkum et al., 2017) such as extracellular carbonic anhydrase (CA) that catalyzes the conversion of $\mathrm{HCO}_{3}{ }^{-}$to $\mathrm{CO}_{2}$ through dehydration, as well as active transport of $\mathrm{HCO}_{3}{ }^{-}$into epidermal cells and subsequent conversion to $\mathrm{CO}_{2}$ by intracellular CA (Beer and Rehnberg, 1997; Borum et al., 2016; Larkum et al., 2017). However, such carbon-concentration machinery, which can be up- and downregulated depending on external environmental conditions (Kim et al., 2018), is energetically more expensive for seagrasses as compared with passive uptake of $\mathrm{CO}_{2} \mathrm{via}$ diffusion (Raven et al., 2014; Larkum et al., 2018). Extreme conditions in the chemical phyllosphere microenvironment can thus reduce leaf photosynthesis and respiration, as well as enable microbial production of reduced toxic compounds within anoxic microzones. This can lead to seagrass die-off events owing to inadequate internal plant aeration and chemical suffocation, respectively.

\section{EFFECTS OF LEAF PHYLLOSPHERE CONDITIONS ON THE SEAGRASS RHIZOSPHERE}

The leaf microenvironment largely controls the internal $\mathrm{O}_{2}$ balance of the seagrass plant over diurnal cycles and thereby the transport of $\mathrm{O}_{2}$ down to the below-ground rhizome and roots of seagrasses (reviewed in Brodersen et al., 2018a). Seagrasses release $\mathrm{O}_{2}$ into the rhizosphere at the base of the leaf (i.e., basal leaf meristem), the root/shoot junctions (i.e., nodes), and at tips (i.e., apical root meristem) of actively growing roots (Pedersen et al., 1998; Jensen et al., 2005; Frederiksen and Glud, 2006; Koren et al., 2015; Brodersen et al., 2016). Such radial $\mathrm{O}_{2}$ loss (ROL) forms oxic microzones, which: (i) protect the seagrass plant against intrusion of reduced toxic compounds such as $\mathrm{H}_{2} \mathrm{~S}$ produced in the surrounding anoxic sediment (Brodersen et al., 2015b, 2018a,b; Martin et al., 2019), and (ii) mobilize nutrients by means of stimulating microbial processes (Welsh et al., 1996; Nielsen et al., 2001; Brodersen et al., 2018b) and chemical solubilization (Brodersen et al., 2017b).

The oxidation capacity of the seagrass below-ground tissue is determined by the efficiency of $\mathrm{O}_{2}$ transport from the leaves and the following $\mathrm{O}_{2}$ release into the sediment, whereas the sediment oxygenation is a balance between the below-ground 

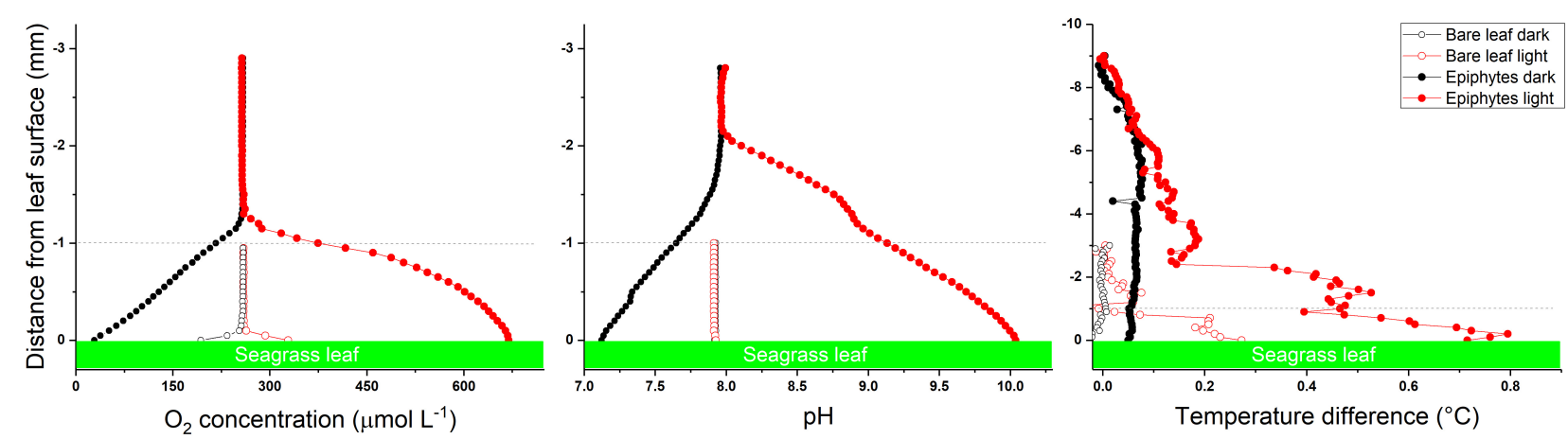

FIGURE 3 | Microsensor profiles of $\mathrm{O}_{2}, \mathrm{pH}$ and temperature at the surface of seagrass leaves with (epiphytes) and without (bare leaves) epiphytes. Data originates from Brodersen et al. (2020a) and Noisette et al. (2020). The dashed line at $1 \mathrm{~mm}$ distance from the leaf tissue surface marks the approximate thickness of the epiphytic biofilm layer. Red symbols and lines represent measurements in light. Black symbols and lines measurements in darkness. Microprofiling data of leaves with epiphytes show that in light the phyllosphere becomes hyperoxic, strongly basified and heated (solid red symbols as compared to open red symbols), whereas phyllopshere hyperoxia and acidification occurs in darkness (solid black symbols as compared with open black symbols); strongly affecting seagrass health and performance.

tissue $\mathrm{O}_{2}$ release and the sediment $\mathrm{O}_{2}$ demand (Borum et al., 2006; Brodersen, 2016; Brodersen et al., 2018a). Within the seagrass rhizosphere, ROL leads to marked reductions in the sediment sulfide concentrations through spontaneous chemical and biological oxidation of $\mathrm{H}_{2} \mathrm{~S}$ (Brodersen et al., 2015b, 2018b; Martin et al., 2019) resulting in an acidification of the seagrass rhizosphere through production of sulfuric acid (Brodersen et al., 2015b, 2016, 2018b). Rhizosphere acidification can also lead to phosphate solubilization in carbonate-rich sediments via protolytic dissolution of Ca-phosphates, while other important nutrients such as ammonium and $\mathrm{Fe}$ (II) can be mobilized via stimulation of the microbial community by plant exudates (Brodersen et al., 2017b); sulfate-reducing bacteria can e.g., fix dinitrogen (Welsh et al., 1996; Nielsen et al., 2001) and solubilize $\mathrm{Fe}$ (II) and $\mathrm{P}$ through reductive dissolution of insoluble $\mathrm{Fe}(\mathrm{III})$ oxyhydroxides (Brodersen et al., 2017b). Changes in the seagrass phyllosphere microenvironment can thus have strong effects on the biogeochemical processes and chemical conditions in the seagrass rhizosphere, and thereby the capacity of the belowground tissue to detoxify reduced compounds and mobilize nutrients in the surrounding sediment. Inadequate internal plant aeration, and subsequent diminished oxic microzones in the rhizosphere, can thus lead to toxic sulfide intrusion and plant starvation, which may kill the plants if persisting over long time periods (Pedersen et al., 2004; Holmer and Hasler-Sheetal, 2014; Brodersen et al., 2015b).

\section{TECHNIQUES FOR MONITORING THE PHYLLOSPHERE MICROENVIRONMENT}

The seagrass phyllosphere represents at thin mm-thick zone surrounding the seagrass leaf and in some cases also encompasses epiphytic biofilms colonizing the leaf surface. Traditionally, microenvironmental analyses of the phyllosphere and rhizosphere of plants have involved use of electrochemical and fiber-optic microsensors (Kühl and Revsbech, 2001; Kühl,
2005; Pedersen et al., 2020; Revsbech, 2021) with tip sizes typically ranging from $\sim 5$ to $100 \mu \mathrm{m}$. Such microsensors enable minimally invasive profiling of physical (light, temperature, diffusivity) and chemical (gases and ions) analytes at high specificity and spatio-temporal resolution around and within plant tissue at specific locations, and their application has gained many fundamental insights to the seagrass microenvironment (see previous sections; Figure 3). While it is possible to use microsensors to map 2D transects and even $3 \mathrm{D}$ grids of microprofiles, e.g., over plant tissue topographies (Lichtenberg et al., 2017), it remains a major challenge to align microsensor measurements and account for spatial heterogeneity in samples with pronounced structural complexity. In recent years, microenvironmental studies of seagrasses are increasingly complemented by chemical imaging approaches, especially for $2 \mathrm{D}$ mapping with optical sensors embedding or appressed to the below-ground seagrass tissue (reviewed in Scholz et al., 2021). The use of magnetic sensor particles in combination with luminescence lifetime imaging has also enabled 2D mapping of $\mathrm{O}_{2}$ over natural flow-exposed surfaces and biofilms (Fabricius-Dyg et al., 2012) and recently, a first application studying the heterogeneous $\mathrm{O}_{2}$ microenvironment of epiphytic biofilms on seagrass leaves was reported (Brodersen et al., 2020b). Suitable sensor particles have been developed for a variety of analytes in the aquatic environment (Moßhammer et al., 2019), and we envision that this approach can relatively easily be extended to imaging other chemical species (e.g., $\mathrm{pH}$ ) in the seagrass phyllosphere. Furthermore, combining such sensor particle-based imaging with e.g., light sheet or confocal microscopy systems could enable true 3D mapping of the chemical phyllosphere microenvironment.

\section{CONCLUSION AND PERSPECTIVES}

Coastal eutrophication is a major environmental stressor stimulating dense epiphytic biofilm growth on seagrass leaves. 
Increased epiphyte colonization shades the seagrass leaves, and the increasing diffusion distance between the leaf and surrounding water can result in phyllosphere basification, warming and hyperoxia, leading to carbon limitation and enhanced photorespiration in the light. During darkness, anoxic stress in the seagrass phyllosphere owing to restricted diffusional $\mathrm{O}_{2}$ supply across the epiphytic biofilm layer from the surrounding water-column and/or heterotrophic activity in the biofilm can induce production of reduced toxic substances that can diffuse into the plant tissue and potentially cause increased mortality. Finally, reduced leaf $\mathrm{O}_{2}$ evolution or diffusional supply from the adjacent water decreases $\mathrm{O}_{2}$ transport to the root/rhizome system and subsequent release to the reduced sediment increasing the risk of $\mathrm{H}_{2} \mathrm{~S}$ intrusion and plant nutrient limitation.

The biomass of the seagrass leaf-associated epiphytic communities is largely driven by progressive enrichment of seawater with minerals and nutrients, wherefore leaf epiphyte blooms mainly follow algal blooms in the watercolumn that mostly occur during spring (April-May) and autumn (Aug-Sep) time in northern temperate waters (Borum et al., 1984). These time windows thus represent the most critical periods during the annual growth season of the seagrass plant. Furthermore, ocean acidification can lead to a shift in the seagrass epiphyte community structure by increasing the fleshy/calcareous algal taxa ratio (Campbell and Fourqurean, 2014), which may impose further shading and impede mass transfer in seagrasses owing to the increased epiphytic biomass load on the seagrass leaves. This is supported by recent findings near $\mathrm{CO}_{2}$ seeps, where seagrass leaves often appear free of calcifying epiphytes (e.g., Mishra et al., 2020); however, the underlying mechanisms for epiphyte colonization at $\mathrm{CO}_{2}$ seeps are not well understood. Future

\section{REFERENCES}

Arasimowicz, M., and Floryszak-Wieczorek, J. (2007). Nitric oxide as a bioactive signalling molecule in plant stress responses. Plant Sci. 172, 876-887. doi: 10. 1016/j.plantsci.2007.02.005

Armstrong, W. (1979). "Aeration in higher plants," in Advances in Botanical Research, Vol. 7, ed. H. W. Woolhouse (London: Academic Press), 225-332. doi: 10.1016/S0065-2296(08)60089-0

Ballesteros, E., Cebrian, E., and Alcoverro, T. (2007). Mortality of shoots of Posidonia oceanica following meadow invasion by the red alga Lophocladia lallemandii. Botanica Marina 50, 8-13. doi: 10.1515/BOT.2007.002

Beer, S., Bjork, M., Hellblom, F., and Axelsson, L. (2002). Inorganic carbon utilization in marine angiosperms (seagrasses). Funct. Plant Biol. 29, 349-354. doi: 10.1071/PP01185

Beer, S., and Rehnberg, J. (1997). The acquisition of inorganic carbon by the seagrass Zostera marina. Aquatic Bot. 56, 277-283. doi: 10.1016/S0304-3770(96) 01109-6

Beer, S., Shomer-Ilan, A., and Waisel, Y. (1980). Carbon metabolism in seagrasses: II. Patterns of photosynthetic $\mathrm{CO}_{2}$ incorporation. J. Exp. Bot. 31, 1019-1026. doi: $10.1093 / \mathrm{jxb} / 31.4 .1019$

Beligni, M., and Lamattina, L. (2001). Nitric oxide in plants: the history is just beginning. Plant Cell Environ. 24, 267-278. doi: 10.1046/j.1365-3040.2001. 00672.x

Bertelli, C. M., and Unsworth, R. K. (2014). Protecting the hand that feeds us: seagrass (Zostera marina) serves as commercial juvenile fish habitat. Mar. Pollut. Bull. 83, 425-429. doi: 10.1016/j.marpolbul.2013.08.011 climate conditions with heavier precipitation driving more frequent coastal eutrophication events, in combination with ocean acidification, can thus potentially lead to enhanced and shifting leaf epiphyte communities putting seagrass ecosystems at risk of local-extinction, especially in combination with further environmental stress factors such as ocean deoxygenation and/or extreme heating events.

However, pronounced knowledge gaps about the seagrass leaf microenvironment and the role of leaf epiphytes on seagrass plant fitness prevail and encompass: (i) a detailed determination of the nitrogen cycling in the phyllosphere to better understand the role of epiphytic biofilms for plant nutrition and potential production of phytotoxins, (ii) a better understanding of the optical properties of the seagrass leaf tissue and the leaf microenvironmental landscape, including how it is affected by leaf epiphytes, and (iii) how leaves and epiphytism in seagrass acclimate to future climate conditions, including seagrass expansion to cold and light-limiting Artic regions.

\section{AUTHOR CONTRIBUTIONS}

$\mathrm{KB}$ and MK developed the concept for this review and wrote the manuscript. Both authors contributed to the article and approved the submitted version.

\section{FUNDING}

We would like to acknowledge financial support from the Carlsberg Foundation (KB: project no. CF16-0899), the Villum Foundation (KB: project no. 00028156), and the Independent Research Fund Denmark (MK: project no. DFF-8021-00308B).

Borum, J. (1985). Development of epiphytic communities on eelgrass (Zostera marina) along a nutrient gradient in a Danish estuary. Mar. Biol. 87, 211-218. doi: 10.1007/BF00539431

Borum, J., Kaas, H., and Wium-Andersen, S. (1984). Biomass variation and autotrophic production of an epiphyte-macrophyte community in a coastal Danish area: II. Epiphyte species composition, biomass and production. Ophelia 23, 165-179. doi: 10.1080/00785326.1984.1042 6612

Borum, J., Pedersen, O., Greve, T. M., Frankovich, T. A., Zieman, J. C., Fourqurean, J. W., et al. (2005). The potential role of plant oxygen and sulphide dynamics in die-off events of the tropical seagrass, Thalassia testudinum. J. Ecol. 93, 148-158. doi: 10.1111/j.1365-2745.2004.00943.x

Borum, J., Pedersen, O., Kotula, L., Fraser, M. W., Statton, J., Colmer, T. D., et al. (2016). Photosynthetic response to globally increasing $\mathrm{CO}_{2}$ of co-occurring temperate seagrass species. Plant Cell Environ. 39, 1240-1250. doi: 10.1111/ pce. 12658

Borum, J., Sand-Jensen, K., Binzer, T., Pedersen, O., and Greve, T. (2006). “Oxygen movement in seagrasses," in Seagrasses: Biology, Ecology and Conservation, eds A. W. D. Larkum, J. R. Orth, and C. M. Duarte (Dordrecht: Springer), 255-270. doi: 10.1007/1-4020-2983-7_10

Brodersen, K. E. (2016). The Seagrass Rhizosphere. Ph.D. thesis. Sydney: University of Technology Sydney.

Brodersen, K. E., Hammer, K. J., Schrameyer, V., Floytrup, A., Rasheed, M. A., Ralph, P. J., et al. (2017a). Sediment resuspension and deposition on seagrass leaves impedes internal plant aeration and promotes phytotoxic $\mathrm{H}_{2} \mathrm{~S}$ intrusion. Front. Plant Sci. 8:657. doi: 10.3389/fpls.2017.00657 
Brodersen, K. E., Koren, K., Moßhammer, M., Ralph, P. J., Kühl, M., and Santner, J. (2017b). Seagrass-mediated phosphorus and iron solubilization in tropical sediments. Environ. Sci. Technol. 51, 14155-14163. doi: 10.1021/acs. est.7b03878

Brodersen, K. E., Koren, K., Lichtenberg, M., and Kühl, M. (2016). Nanoparticlebased measurements of $\mathrm{pH}$ and $\mathrm{O}_{2}$ dynamics in the rhizosphere of Zostera marina L.: effects of temperature elevation and light/dark transitions. Plant Cell Environ. 39, 1619-1630. doi: 10.1111/pce.12740

Brodersen, K. E., Koren, K., Revsbech, N. P., and Kühl, M. (2020a). Strong leaf surface basification and $\mathrm{CO}_{2}$ limitation of seagrass induced by epiphytic biofilm microenvironments. Plant Cell Environ. 43, 174-187. doi: 10.1111/pce.13645

Brodersen, K. E., Kühl, M., Trampe, E., and Koren, K. (2020b). Imaging $\mathrm{O}_{2}$ dynamics and microenvironments in the seagrass leaf phyllosphere with magnetic optical sensor nanoparticles. Plant J. 104, 1504-1519. doi: 10.1111/ tpj.15017

Brodersen, K. E., Kühl, M., Nielsen, D. A., Pedersen, O., and Larkum, A. W. (2018a). "Rhizome, root/sediment interactions, aerenchyma and internal pressure changes in seagrasses," in Seagrasses of Australia, eds A. Larkum, G. Kendrick, and P. Ralph (Cham: Springer), 393-418. doi: 10.1007/978-3-31971354-0_13

Brodersen, K. E., Siboni, N., Nielsen, D. A., Pernice, M., Ralph, P. J., Seymour, J., et al. (2018b). Seagrass rhizosphere microenvironment alters plant-associated microbial community composition. Environ. Microbiol. 20, 2854-2864. doi: 10.1111/1462-2920.14245

Brodersen, K. E., Lichtenberg, M., Paz, L.-C., and Kühl, M. (2015a). Epiphyte-cover on seagrass (Zostera marina L.) leaves impedes plant performance and radial $\mathrm{O}_{2}$ loss from the below-ground tissue. Front. Mar. Sci. 2:58. doi: 10.3389/fmars. 2015.00058

Brodersen, K. E., Nielsen, D. A., Ralph, P. J., and Kühl, M. (2015b). Oxic microshield and local $\mathrm{pH}$ enhancement protects Zostera muelleri from sediment derived hydrogen sulphide. New Phytol. 205, 1264-1276. doi: 10.1111/nph. 13124

Brodersen, K. E., Lichtenberg, M., Ralph, P. J., Kühl, M., and Wangpraseurt, D. (2014). Radiative energy budget reveals high photosynthetic efficiency in symbiont-bearing corals. J. R. Soc. Interface 11:20130997. doi: 10.1098/rsif. 2013.0997

Brush, M. J., and Nixon, S. W. (2002). Direct measurements of light attenuation by epiphytes on eelgrass Zostera marina. Mar. Ecol. Progr. Series 238, 73-79. doi: $10.3354 /$ meps 238073

Buapet, P., and Björk, M. (2016). The role of $\mathrm{O}_{2}$ as an electron acceptor alternative to $\mathrm{CO}_{2}$ in photosynthesis of the common marine angiosperm Zostera marina L. Photosynthesis Res. 129, 59-69. doi: 10.1007/s11120-016-0268-4

Burkholder, J. M., Tomasko, D. A., and Touchette, B. W. (2007). Seagrasses and eutrophication. J. Exp. Mar. Biol. Ecol. 350, 46-72. doi: 10.1016/j.jembe.2007. 06.024

Campbell, J. E., and Fourqurean, J. W. (2014). Ocean acidification outweighs nutrient effects in structuring seagrass epiphyte communities. J. Ecol. 102, 730-737. doi: 10.1111/1365-2745.12233

Colmer, T. D. (2003). Long-distance transport of gases in plants: a perspective on internal aeration and radial oxygen loss from roots. Plant Cell Environ. 26, 17-36. doi: 10.1046/j.1365-3040.2003.00846.x

Costa, M. M., Barrote, I., Silva, J., Olivé, I., Alexandre, A., Albano, S., et al. (2015). Epiphytes modulate Posidonia oceanica photosynthetic production, energetic balance, antioxidant mechanisms, and oxidative damage. Front. Mar. Sci. 2:111. doi: 10.3389/fmars.2015.00111

Dennison, W. C., Orth, R. J., Moore, K. A., Stevenson, J. C., Carter, V., Kollar, S., et al. (1993). Assessing water quality with submersed aquatic vegetation. BioScience 43, 86-94. doi: 10.2307/1311969

Diaz, R. J., and Rosenberg, R. (2008). Spreading dead zones and consequences for marine ecosystems. Science 321, 926-929. doi: 10.1126/science.115 6401

Drake, L. A., Dobbs, F. C., and Zimmerman, R. C. (2003). Effects of epiphyte load on optical properties and photosynthetic potential of the seagrasses Thalassia testudinum Banks ex König and Zostera marina L. Limnol. Oceanogr. 48(Part 2), 456-463. doi: 10.4319/lo.2003.48.1_part_2.0456

Duarte, C. M. (1991). Seagrass depth limits. Aquatic Bot. 40, 363-377. doi: 10.1016/ 0304-3770(91)90081-F
Duarte, C. M., Middelburg, J., and Caraco, N. (2005). Major role of marine vegetation on the oceanic carbon cycle. Biogeosciences 2, 1-8. doi: 10.5194/bg2-1-2005

Enriquez, S., Méndez, E. R., and Iglesias-Prieto, R. (2005). Multiple scattering on coral skeletons enhances light absorption by symbiotic algae. Limnol. Oceanogr. 50, 1025-1032. doi: 10.4319/lo.2005.50.4.1025

Erftemeijer, P. L. A., and Lewis, R. R. R. (2006). Environmental impacts of dredging on seagrasses: a review. Mar. Pollut. Bull. 52, 1553-1572. doi: 10.1016/j. marpolbul.2006.09.006

Fabricius-Dyg, J., Mistlberger, G., Staal, M., Borisov, S. M., Klimant, I., and Kühl, M. (2012). Imaging of surface $\mathrm{O}_{2}$ dynamics in corals with magnetic micro optode particles. Mar. Biol. 159, 1621-1631. doi: 10.1007/s00227-012-1920-y

Falkowski, P. G., and Raven, J. A. (2013). Aquatic Photosynthesis. New Jersey, NJ: Princeton University Press.

Fonseca, M. S., and Cahalan, J. A. (1992). A preliminary evaluation of wave attenuation by four species of seagrass. Estuarine Coastal Shelf Sci. 35, 565-576. doi: 10.1016/S0272-7714(05)80039-3

Fourqurean, J. W., Duarte, C. M., Kennedy, H., Marba, N., Holmer, M., Mateo, M. A., et al. (2012). Seagrass ecosystems as a globally significant carbon stock. Nat. Geosci. 5, 505-509. doi: 10.1038/ngeo1477

Frankovich, T. A., and Fourqurean, J. W. (1997). Seagrass epiphyte loads along a nutrient availability gradient, Florida Bay, USA. Mar. Ecol. Progr. Series 159, 37-50. doi: 10.3354/meps 159037

Frederiksen, M. S., and Glud, R. N. (2006). Oxygen dynamics in the rhizosphere of Zostera marina: a two-dimensional planar optode study. Limnol. Oceanogr. 51, 1072-1083. doi: 10.4319/lo.2006.51.2.1072

Greve, T. M., Borum, J., and Pedersen, O. (2003). Meristematic oxygen variability in eelgrass (Zostera marina). Limnol. Oceanogr. 48, 210-216. doi: 10.4319/lo. 2003.48.1.0210

Hamisi, M., Díez, B., Lyimo, T., Ininbergs, K., and Bergman, B. (2013). Epiphytic cyanobacteria of the seagrass Cymodocea rotundata: diversity, diel nifH expression and nitrogenase activity. Environ. Microbiol. Rep. 5, 367-376. doi: $10.1111 / 1758-2229.12031$

Holmer, M., and Bondgaard, E. J. (2001). Photosynthetic and growth response of eelgrass to low oxygen and high sulfide concentrations during hypoxic events. Aquatic Bot. 70, 29-38. doi: 10.1016/S0304-3770(00)00142-X

Holmer, M., and Hasler-Sheetal, H. (2014). Sulfide intrusion in seagrasses assessed by stable sulfur isotopes-a synthesis of current results. Front. Mar. Sci. 1:64. doi: $10.3389 /$ fmars. 2014.00064

Hurd, C. L. (2000). Water motion, marine macroalgal physiology, and production. J. Phycol. 36, 453-472. doi: 10.1046/j.1529-8817.2000.99139.x

Jendresen, C. B., and Nielsen, A. T. (2019). Production of zosteric acid and other sulfated phenolic biochemicals in microbial cell factories. Nat. Commun. 10, 1-10. doi: 10.1038/s41467-019-12022-x

Jensen, S. I., Kühl, M., Glud, R. N., Jørgensen, L. B., and Prieme, A. (2005). Oxic microzones and radial oxygen loss from roots of Zostera marina. Mar. Ecol. Progr. Series 293, 49-58. doi: 10.3354/meps293049

Jimenez, I. M., Kühl, M., Larkum, A., and Ralph, P. J. (2008). Heat budget and thermal microenvironment of shallow-water corals: do massive corals get warmer than branching corals? Limnol. Oceanogr. 53, 1548-1561. doi: 10.4319/ lo.2008.53.4.1548

Jimenez, I. M., Kühl, M., Larkum, A. W., and Ralph, P. J. (2011). Effects of flow and colony morphology on the thermal boundary layer of corals. J. R. Soc. Interface 8, 1785-1795. doi: 10.1098/rsif.2011.0144

Jørgensen, B. B., and Des Marais, D. J. (1990). The diffusive boundary layer of sediments: oxygen microgradients over a microbial mat. Limnol. Oceanogr. 35, 1343-1355. doi: 10.4319/lo.1990.35.6.1343

Jørgensen, B. B., and Revsbech, N. P. (1985). Diffusive boundary layers and the oxygen uptake of sediments and detritus. Limnol. Oceanogr. 30, 111-122. doi: 10.4319/lo.1985.30.1.0111

Kim, M., Brodersen, K. E., Szabó, M., Larkum, A. W., Raven, J. A., Ralph, P. J., et al. (2018). Low oxygen affects photophysiology and the level of expression of twocarbon metabolism genes in the seagrass Zostera muelleri. Photosynthesis Res. 136, 147-160. doi: 10.1007/s11120-017-0452-1

Koch, E. (1994). Hydrodynamics, diffusion-boundary layers and photosynthesis of the seagrasses Thalassia testudinum and Cymodocea nodosa. Mar. Biol. 118, 767-776. doi: 10.1007/BF00347527 
Koren, K., Brodersen, K. E., Jakobsen, S. L., and Kühl, M. (2015). Optical sensor nanoparticles in artificial sediments - a new tool to visualize $\mathrm{O}_{2}$ dynamics around the rhizome and roots of seagrasses. Environ. Sci. Technol. 49, 22862292. doi: 10.1021/es505734b

Kühl, M. (2005). Optical microsensors for analysis of microbial communities. Methods Enzymol. 397, 166-199. doi: 10.1016/S0076-6879(05)97010-9

Kühl, M., and Revsbech, N. P. (2001). "Biogeochemical microsensors for boundary layer studies," in The Benthic Boundary Layer, eds B. P. Boudreau and B. B. Jørgensen (New York, NY: Oxford University Press), 180-210.

Kumar, A., Castellano, I., Patti, F. P., Palumbo, A., and Buia, M. C. (2015). Nitric oxide in marine photosynthetic organisms. Nitric Oxide 47, 34-39. doi: 10. 1016/j.niox.2015.03.001

Larkum, A. W., Pernice, M., Schliep, M., Davey, P., Szabo, M., Raven, J. A., et al. (2018). "Photosynthesis and metabolism of seagrasses," in Seagrasses of Australia, eds A. Larkum, G. Kendrick, and P. Ralph (Cham: Springer), 315-342. doi: 10.1007/978-3-319-71354-0_11

Larkum, A. W. D., Davey, P. A., Kuo, J., Ralph, P. J., and Raven, J. A. (2017). Carbon-concentrating mechanisms in seagrasses. J. Exp. Bot. 68, 3773-3784. doi: $10.1093 / j x b / e r x 206$

Larkum, A. W. D., Orth, R. J., and Duarte, C. M. (2006). Seagrasses: Biology, Ecology and Conservation. Berlin: Springer.

Lichtenberg, M., Nørregaard, R. D., and Kühl, M. (2017). Diffusion or advection? Mass transfer and complex boundary layer landscapes of the brown alga Fucus vesiculosus. J. R. Soc. Interface 14:20161015. doi: 10.1098/rsif.2016.1015

Martin, B. C., Bougoure, J., Ryan, M. H., Bennett, W. W., Colmer, T. D., Joyce, N. K., et al. (2019). Oxygen loss from seagrass roots coincides with colonisation of sulphide-oxidising cable bacteria and reduces sulphide stress. ISME J. 13, 707-719. doi: 10.1038/s41396-018-0308-5

Mazzella, L., and Alberte, R. S. (1986). Light adaptation and the role of autotrophic epiphytes in primary production of the temperate seagrass, Zostera marina $\mathrm{L}$. J. Exp. Mar. Biol. Ecol. 100, 165-180. doi: 10.1016/0022-0981(86)90161-9

McConnaughey, T. (1991). Calcification in Chara corallina: $\mathrm{CO}_{2}$ hydroxylation generates protons for bicarbonate assimilation. Limnol. Oceanogr. 36, 619-628. doi: 10.4319/lo.1991.36.4.0619

McRoy, C. P., and Barsdate, R. J. (1970). Phosphate absorption in eelgrass. Limnol. Oceanogr. 15, 6-13. doi: 10.4319/lo.1970.15.1.0006

Mishra, A. K., Santos, R., and Hall-Spencer, J. (2020). Elevated trace elements in sediments and seagrasses at $\mathrm{CO}_{2}$ seeps. Mar. Environ. Res. 153:104810. doi: 10.1016/j.marenvres.2019.104810

Moßhammer, M., Brodersen, K. E., Kühl, M., and Koren, K. (2019). Nanoparticleand microparticle-based luminescence imaging of chemical species and temperature in aquatic systems: a review. Microchim. Acta 186:126. doi: 10. 1007/s00604-018-3202-y

Newby, B. Z., Cutright, T., Barrios, C. A., and Xu, Q. (2006). Zosteric acid-An effective antifoulant for reducing fresh water bacterial attachment on coatings. JCT Res. 3, 69-76. doi: 10.1007/s11998-006-0007-4

Nguyen, H. M., Ralph, P. J., Marín-Guirao, L., Pernice, M., and Procaccini, G. (2021). Seagrasses in an era of ocean warming: a review. Biol. Rev. 96, 2009-2030. doi: 10.1111/brv.12736

Nielsen, L. B., Finster, K., Welsh, D. T., Donelly, A., Herbert, R. A., De Wit, R., et al. (2001). Sulphate reduction and nitrogen fixation rates associated with roots, rhizomes and sediments from Zostera noltii and Spartina maritima meadows. Environ. Microbiol. 3, 63-71. doi: 10.1046/j.1462-2920.2001.0 0160.x

Noisette, F., Depetris, A., Kühl, M., and Brodersen, K. E. (2020). Flow and epiphyte growth effects on the thermal, optical and chemical microenvironment in the leaf phyllosphere of seagrass (Zostera marina). J. R. Soc. Interface 17:20200485. doi: 10.1098/rsif.2020.0485

Orth, R. J., Heck, K. L., and van Montfrans, J. (1984). Faunal communities in seagrass beds: a review of the influence of plant structure and prey characteristics on predator-prey relationships. Estuaries 7, 339-350. doi: 10. 2307/1351618

Orth, R. J., and Van Montfrans, J. (1984). Epiphyte-seagrass relationships with an emphasis on the role of micrograzing: a review. Aquatic Bot. 18, 43-69. doi: 10.1016/0304-3770(84)90080-9

Pedersen, O., Binzer, T., and Borum, J. (2004). Sulphide intrusion in eelgrass (Zostera marina L.). Plant Cell Environ. 27, 595-602. doi: 10.1111/j.1365-3040. 2004.01173.x
Pedersen, O., Borum, J., Duarte, C. M., and Fortes, M. D. (1998). Oxygen dynamics in the rhizosphere of Cymodocea rotundata. Mar. Ecol. Progr. Series 169, 283-288. doi: 10.3354/meps169283

Pedersen, O., Colmer, T. D., Borum, J., Zavala-Perez, A., and Kendrick, G. A. (2016). Heat stress of two tropical seagrass species during low tides-impact on underwater net photosynthesis, dark respiration and diel in situ internal aeration. New Phytol. 210, 1207-1218. doi: 10.1111/nph.13900

Pedersen, O., Revsbech, N. P., and Shabala, S. (2020). Microsensors in plant biology: in vivo visualization of inorganic analytes with high spatial and/or temporal resolution. J. Exp. Bot. 71, 3941-3954. doi: 10.1093/jxb/eraa175

Pernice, M., Sinutok, S., Sablok, G., Commault, A. S., Schliep, M., Macreadie, P. I., et al. (2016). Molecular physiology reveals ammonium uptake and related gene expression in the seagrass Zostera muelleri. Mar. Environ. Res. 122, 126-134. doi: 10.1016/j.marenvres.2016.10.003

Ralph, P. J., Tomasko, D., Moore, K., Seddon, S., and Macinnis-Ng, C. M. (2007). "Human impacts on seagrasses: eutrophication, sedimentation, and contamination," in Seagrasses: Biology, Ecology and Conservation, eds A. W. D. Larkum, R. J. Orth, and C. M. Duarte (Cham: Springer), 567-593. doi: 10.1007/1-4020-2983-7_24

Rasmusson, L. M., Buapet, P., George, R., Gullström, M., Gunnarsson, P. C., and Björk, M. (2020). Effects of temperature and hypoxia on respiration, photorespiration, and photosynthesis of seagrass leaves from contrasting temperature regimes. ICES J. Mar. Sci. 77, 2056-2065. doi: 10.1093/icesjms/ fsaa093

Raun, A. L., and Borum, J. (2013). Combined impact of water column oxygen and temperature on internal oxygen status and growth of Zostera marina seedlings and adult shoots. J. Exp. Mar. Biol. Ecol. 441, 16-22. doi: 10.1016/j.jembe.2013. 01.014

Raven, J. A., Beardall, J., and Giordano, M. (2014). Energy costs of carbon dioxide concentrating mechanisms in aquatic organisms. Photosynthesis Res. 121, 111-124. doi: 10.1007/s11120-013-9962-7

Revsbech, N. P. (2021). Simple sensors that work in diverse natural environments: the micro-Clark sensor and biosensor family. Sensors Actuators B: Chem. 329:129168. doi: 10.1016/j.snb.2020.129168

Ricart, A. M., Ward, M., Hill, T. M., Sanford, E., Kroeker, K. J., Takeshita, Y., et al. (2021). Coast-wide evidence of low $\mathrm{pH}$ amelioration by seagrass ecosystems. Global Change Biol. 27, 2580-2591. doi: 10.1111/gcb.15594

Riebesell, U., Zondervan, I., Rost, B., Tortell, P. D., Zeebe, R. E., and Morel, F. M. (2000). Reduced calcification of marine plankton in response to increased atmospheric $\mathrm{CO}_{2}$. Nature 407, 364-367. doi: 10.1038/35030078

Sand-Jensen, K. (1977). Effect of epiphytes on eelgrass photosynthesis. Aquatic Bot. 3(Suppl. C), 55-63. doi: 10.1016/0304-3770(77)90004-3

Scholz, V. V., Brodersen, K. E., Kühl, M., and Koren, K. (2021). Resolving chemical gradients around seagrass roots-a review of available methods. Front. Mar. Sci. 1597. doi: $10.3389 /$ fmars.2021.771382

Staehr, P. A., and Borum, J. (2011). Seasonal acclimation in metabolism reduces light requirements of eelgrass (Zostera marina). J. Exp. Mar. Biol. Ecol. 407, 139-146. doi: 10.1016/j.jembe.2011.05.031

Sullivan, B. K., Sherman, T. D., Damare, V. S., Lilje, O., and Gleason, F. H. (2013). Potential roles of Labyrinthula spp. in global seagrass population declines. Fungal Ecol. 6, 328-338. doi: 10.1016/j.funeco.2013.06.004

Sullivan, B. K., Trevathan-Tackett, S. M., Neuhauser, S., and Govers, L. L. (2018). Review: host-pathogen dynamics of seagrass diseases under future global change. Mar. Pollut. Bull. 134, 75-88. doi: 10.1016/j.marpolbul.2017.09.030

Tarquinio, F., Bourgoure, J., Koenders, A., Laverock, B., Säwström, C., and Hyndes, G. A. (2018). Microorganisms facilitate uptake of dissolved organic nitrogen by seagrass leaves. ISME J. 12, 2796-2800. doi: 10.1038/s41396-018-0218-6

Trevathan-Tackett, S. M., Sullivan, B. K., Robinson, K., Lilje, O., Macreadie, P. I., and Gleason, F. H. (2018). Pathogenic Labyrinthula associated with Australian seagrasses: considerations for seagrass wasting disease in the southern hemisphere. Microbiol. Res. 206, 74-81. doi: 10.1016/j.micres.2017. 10.003

Van Dam, B., Zeller, M., Lopes, C., Smyth, A., Böttcher, M., Osburn, C., et al. (2021) Calcification-driven $\mathrm{CO}_{2}$ emissions exceed "Blue Carbon" sequestration in a carbonate seagrass meadow. Sci. Adv. 7:eabj1372. doi: 10.1126/sciadv.abj1372

Villa, F., Albanese, D., Giussani, B., Stewart, P. S., Daffonchio, D., and Cappitelli, F. (2010). Hindering biofilm formation with zosteric acid. Biofouling 26, 739-752. doi: $10.1080 / 08927014.2010 .511197$ 
Wangpraseurt, D., Larkum, A. W., Ralph, P. J., and Kühl, M. (2012). Light gradients and optical microniches in coral tissues. Front. Microbiol. 3:316. doi: 10.3389/ fmicb. 2012.00316

Ward, L. G., Kemp, W. M., and Boynton, W. R. (1984). The influence of waves and seagrass communities on suspended particulates in an estuarine embayment. Mar. Geol. 59, 85-103. doi: 10.1016/0025-3227(84)90089-6

Waycott, M., Duarte, C. M., Carruthers, T. J. B., Orth, R. J., Dennison, W. C., Olyarnik, S., et al. (2009). Accelerating loss of seagrasses across the globe threatens coastal ecosystems. Proc. Natl. Acad. Sci. U.S.A. 106, 12377-12381. doi: $10.1073 /$ pnas.0905620106

Welsh, D. T., Wellsbury, P., Bourguès, S., de Wit, R., and Herbert, R. A. (1996). Relationship between porewater organic carbon content, sulphate reduction and nitrogen fixation (acetylene reduction) in the rhizosphere of Zostera noltii. Hydrobiologia 329, 175-183. doi: 10.1007/BF00034556

York, P. H., Carter, A. B., Chartrand, K., Sankey, T., Wells, L., and Rasheed, M. A. (2015). Dynamics of a deep-water seagrass population on the Great Barrier Reef: annual occurrence and response to a major dredging program. Sci. Rep. 5:13167. doi: $10.1038 /$ srep 13167

York, P. H., Smith, T. M., Coles, R. G., McKenna, S. A., Connolly, R. M., Irving, A. D., et al. (2016). Identifying knowledge gaps in seagrass research and management: an Australian perspective. Mar. Environ. Res. 127, 163-172. doi: 10.1016/j.marenvres.2016.06.006
Zhang, Q., Kühl, M., and Brodersen, K. E. (2022). Effects of epiphytic biofilm activity on the photosynthetic activity, $\mathrm{pH}$ and inorganic carbon microenvironment of seagrass leaves (Zostera marina L.). Front. Mar. Sci. 9:835381.

Conflict of Interest: The authors declare that the research was conducted in the absence of any commercial or financial relationships that could be construed as a potential conflict of interest.

Publisher's Note: All claims expressed in this article are solely those of the authors and do not necessarily represent those of their affiliated organizations, or those of the publisher, the editors and the reviewers. Any product that may be evaluated in this article, or claim that may be made by its manufacturer, is not guaranteed or endorsed by the publisher.

Copyright (c) 2022 Brodersen and Kühl. This is an open-access article distributed under the terms of the Creative Commons Attribution License (CC BY). The use, distribution or reproduction in other forums is permitted, provided the original author(s) and the copyright owner(s) are credited and that the original publication in this journal is cited, in accordance with accepted academic practice. No use, distribution or reproduction is permitted which does not comply with these terms. 